\title{
NEW INSIGHTS INTO GRAUSA: REINSTATEMENT,DISTRIBUTION AND AFFINITIES OF LOASA ACAULIS (LOASACEAE, LOASOIDEAE)
}

\author{
Ludovica Santilli' ${ }^{1}$, Dylan H. Cohen² \& Rafael Acuña ${ }^{3}$
}

\author{
${ }^{1}$ Museo Nacional de Historia Natural, Área Botánica, Interior Parque Quinta Normal S/N, Casilla 787, Santiago, \\ Chile; santilli.ludovica@gmail.com \\ ${ }^{2}$ Rancho Santa Ana Botanic Garden, 1500 North College Avenue, Claremont, California, United States of America; \\ dcohen@rsabg.org \\ ${ }^{3}$ Universidad de Costa Rica, Escuela de Biología, Apdo 11501-2060, San Pedro de Montes de Oca, Costa Rica; \\ rafael.acuna_cast@ucr.ac.cr (autor corresponsal).
}

Abstract. Santilli, L.; D. H. Cohen \& R. Acuña. 2020. New Insights into Grausa: Reinstatement, distribution and affinities of Loasa acaulis (Loasaceae, Loasoideae). Darwiniana, nueva serie 8(1): 372-388.

Through the study of the original description, types, herbarium material, fieldwork and molecular evidence, Loasa acaulis is reinstated, lectotypified and transferred to Grausa. Loasa acaulis was previously synonymized under Loasa lateritia. We now consider both as two different species for which a key and descriptions are herein provided. Key floral differences include size, shape, angle and colour of petals, shape of the nectar scales, and attachment position of the dorsal threads. We found no specimens that resembled intermediate floral morphologies. Scanning Electron Microscope studies of mature seeds show a strong affinity between the two species as they lack the outer periclinal walls and incomplete fenestration found in other members of Grausa. Additionally, the characteristic hilar cone of other species of Grausa, is always poorly developed in L. acaulis and G. lateritia. We sequenced five loci (four plastid and one nuclear) and inferred topologies with Maximum Likelihood and Bayesian approaches. Both plastid and nuclear phylogenies placed Loasa acaulis as sister to Grausa lateritia, and distantly related to Blumenbachia and Loasa. Finally, examination of herbarium specimens revealed that Loasa acaulis is not endemic to Chile as previously thought, but also found in adjacent Argentina.

Keywords. Grausa; Loasaceae; molecular phylogeny; reinstatement; Southern Andes; taxonomy.

Resumen. Santilli, L.; D. H. Cohen \& R. Acuña. 2020. Nueva información sobre Grausa: Revalidación, distribución y afinidades de Loasa acaulis (Loasaceae, Loasoideae). Darwiniana, nueva serie 8(1): 372-388.

Gracias al estudio de la descripción original, tipos, material del herbario, trabajo de campo y evidencia molecular, Loasa acaulis es restablecida, lectotipificada y transferida a Grausa. Loasa acaulis fue sinonimizada anteriormente con Loasa lateritia. Ahora consideramos a ambas como dos especies diferentes para las cuales se proporcionan una clave y descripciones detalladas. Las diferencias florales clave incluyen el tamaño, forma, ángulo y color de los pétalos, la forma de las escamas de néctar y la posición de los filamentos dorsales en las escamas. No se localizaron especímenes que mostraran morfologías florales intermedias entre ambas especies. Los estudios de microscopio electrónico de barrido de semillas maduras muestran una fuerte afinidad entre las dos especies, ya que carecen tanto de las paredes periclinales externas como de la fenestración incompleta que se encuentra en otros miembros de Grausa. Además, el cono hilar característico de otras especies de Grausa, está menos desarrollado en L. acaulis y G. lateritia. Se secuenciaron cinco loci (cuatro plastidiales y uno nuclear) para análisis moleculares y se obtuvieron filogenias bajo enfoques de Máxima Verosimilitud y Bayesianos. Tanto las filogenias plastidiales como las nucleares ubicaron a Loasa acaulis como hermana de Grausa lateritia, ambas lejanamente emparentadas con Blumenbachia y Loasa. Finalmente, el estudio de especímenes de herbario reveló que Loasa acaulis no es endémica de Chile como se pensaba anteriormente, sino que también se encuentra en Argentina.

Palabras clave. Andes australes; filogenia molecular; Grausa; Loasaceae; revalidación; taxonomía. 


\section{INTRODUCTION}

Blumenbachia acaulis Phil. was described by R. A. Philippi (1893), from specimens collected by Carlos Rahmer in 1887 in Trapa Trapa, Araucanía (Biobío region, Chile). Philippi placed this species in Blumenbachia Schrad. based on its alleged similarity with Blumenbachia prietea Gay, however he clearly states that he did not see the fruits of Rahmer's specimens. Subsequently, in "Monographia Loasacearum," Urban \& Gilg (1900) transferred the taxon to Loasa Adans. ser. Acaules Urb. \& Gilg and, with Loasa lateritia Gillies ex Arn., treating both as different species, but considering them to be closely related. Although Philippi (1893) stated that the species has white petals (petalis albis), both Urban \& Gilg (1900) and Reiche (1901) inferred erroneously that they were probably brick red colored (Flores [...] verisimiliter lateritii). Sleumer (1955) believed that only L. lateritia was found in Argentina, and that Loasa acaulis (Phil.) Urb. \& Gilg was endemic to Trapa Trapa. He examined two specimens from Neuquén, Argentina (Comber 542 and 1186, at least the first had green/white flowers), and considered them both as L. lateritia. Regardless of flower color, he thought $L$. acaulis was probably identical to $L$. lateritia (L. acaulis ist bisher nur von Trapa-trapa [...] bekannt und vermutlich mit $\mathrm{L}$. lateritia identisch). Marticorena \& Quezada (1985) recognized both species as valid, although they did not make further remarks. Pérez-Moreau \& Crespo (1988) did not mention L. acaulis in their revision, and specimens with white corollas were considered as L. lateritia along with those with red corollas. Weigend et al. (2008) were the first to formally synonymize $L$. acaulis under L. lateritia. This was followed by Rodríguez et al. (2018) and Zuloaga et al. (2019) in the most recent Catalogues of Vascular Plants of Chile and the Southern Cone respectively. Since the last three works consist of catalogues, the authors do not specify the reasons behind their conclusions.

Early molecular analyses concluded that $L$. lateritia was sister to L. gayana Urb. \& Gilg. and probably to the other Loasa ser. Volubiles Urb. \& Gilg (Weigend et al., 2004; Hufford et al., 2005). Recent molecular analysis resolved major clades within the "South Andean Loasas" (SAL) clade and supported the segregation of Loasa ser.
Volubiles and ser. Acaules from Loasa s.s. into the new genus Grausa Weigend \& R.H. Acuña (Acuña et al., 2017). Both L. ser. Volubiles and Acaules were found to be more closely related to Pinnasa Weigend \& R.H. Acuña, Caiophora C. Presl and Scyphanthus Sweet than to Loasa acanthifolia Desr. (the type species of Loasa). Grausa includes mostly twining species, endemic to low elevations in Chile, from Valparaíso to Los Lagos [G. gayana (Urb. \& Gilg) Weigend \& R.H. Acuña, G. martini (Phil.) Weigend \& R.H. Acuña, G. micrantha (Poepp.) Weigend \& R.H. Acuña, the type species, and G. sagittata (Hook. \& Arn.) Weigend \& R.H. Acuña], but also the acaulescent, high-Andean G. lateritia. As Loasa acaulis was considered a synonym of $L$. lateritia it was implicitly assumed that it was also part of Grausa, however this has never been tested using phylogenetic (molecular or otherwise) evidence.

The present work aims at rehabilitating Loasa acaulis, testing its phylogenetic affinities and making a new combination by transferring the taxon to the genus Grausa, based on morphological and molecular evidence.

\section{MATERIALS AND METHODS}

Detailed examination of preserved specimens of Grausa lateritia and Loasa acaulis (including extant type material) was carried out on specimens or photographs of specimens deposited at the herbaria: B, BAB, BM, BONN, CONC, CORD, E, EIF, F, GH, K, L, M, P, RSA, SGO, U and US (Thiers, 2017). Further observations and measurements were made on specimens collected by the authors during field trips (2019-2020) to Parque Nacional Conguillío (Araucanía), Laguna de Teno (Maule), Reserva Natural Altos de Lircay (Maule) and Termas de Chillán (Ñuble). Collections of these plants are deposited in CONC, EIF, SGO and RSA.

\section{Collection localities}

Laguna Teno is located at the base of volcán El Planchón, whose glacier provides water to the lagoon, in the Andes of the Nuble region. The lagoon is found at $2552 \mathrm{~m}$ a.s.l., where temperatures range between -11 and $14^{\circ} \mathrm{C}$, and average precipitation is $1227 \mathrm{~mm} /$ year. 
Altos de Lircay National Reserve is located in the pre-Andes of the Maule region. The vegetation is dominated by deciduous Nothofagus obliqua (Mirb.) Oerst. forests, and a mixed deciduoussclerophyll shrubland of Nothofagus antarctica (G. Forst) Oerst. In winter time, temperatures range between $5-18{ }^{\circ} \mathrm{C}$ and can reach as high as $30^{\circ} \mathrm{C}$ in summer. Precipitation ranges between 1550-2000 $\mathrm{mm} / \mathrm{year}$, and snowfall can reach between $60-80$ cm high (de la Barrera et al., 2011).

The southern Andean volcanic complex Nevados de Chillán is located in the Nuble region, in a transition zone between central Chilean Mediterranean vegetation, and the temperate evergreen forests of southern Chile. The vegetation limit is at $2700 \mathrm{~m}$ a.s.l. and the tree-line at $2100 \mathrm{~m}$ a.s.l. (Pfanzelt et al., 2008).

Conguillio National Park is located in the Andes of the Araucanía region and was declared a National Park in 1950. Climate is warm-temperate, with mean temperatures of $15.1^{\circ} \mathrm{C}$ in summer and 6.0 ${ }^{\circ} \mathrm{C}$ in winter; precipitation ranges between 1500 to $2500 \mathrm{~mm} /$ year. Above $1400 \mathrm{~m}$ a.s.l., temperatures frequently drop below $0{ }^{\circ} \mathrm{C}$ and precipitations increase to $3000 \mathrm{~mm} /$ year (Rubio et al., 2013). Two volcanoes, Llaima and Sierra Nevada, have modelled the landscape through their activity and today the National Park hosts a great variety of ecosystems. Along with the Andean-Patagonian forests and the Andean deciduous forests (Gajardo, 1983), other ecosystems found here include wetlands, volcanic deposits, and alpine areas (CONAF, 2006).

\section{Morphological Studies}

Scanning Electron Microscope (SEM) studies were performed on seeds of $L$. acaulis and $G$. lateritia to describe and investigate differences between them. The seeds of $L$. acaulis and $G$. lateritia were collected from the herbarium specimens (L. Flores s.n. SGO152473) or the field (Altos de Lircay) and were sputter coated lightly with Pd for about 20 seconds in a SCD040 (Balzers Union, Liechtenstein) or with Au for 60 seconds in a DESK V (Dentom Vacuum, USA) respectively, in order to increase their electrical conductivity. Due to the very low water content, dehydration was not necessary to obtain good quality images. After seeds were sputter coated, they were viewed using a Hitachi TM3000 SEM.

\section{Molecular Studies}

Our sampling for the molecular study included 81 species (ca. 25\%) of Loasaceae, plus six asterids which broadly mirrored sampling from Acuña et al. (2017). All currently recognized genera and most major infrageneric clades of Loasaceae subfamily Loasoideae were included. In addition, we used Mentzelia L. (Loasaceae), Gronovia L. (Loasaceae), Eucnide Zucc. (Loasaceae), Philadelphus L. (Hydrangeaceae), Deutzia Thunb. (Hydrangeaceae), Actinidia chinensis Planch. (Actinidiaceae), Antirrhinum majus L. (Plantaginaceae), and Panax ginseng C.A. Mey. (Araliaceae) as outgroups. All vouchers, including GenBank accession numbers, are listed in the Appendix.

One exemplar of Grausa lateritia (Santilli \& Lavandero 25) and one exemplar of Loasa acaulis (Brownless \& al. DCI 995) were processed for the present work. Total genomic DNA was extracted from silica-dried or herbarium material using the Qiagen DNeasy Plant Mini Kit (QIAGEN) following the manufacturer's instructions or with a modified CTAB method (Doyle \& Doyle 1987). We sequenced the plastid regions $\operatorname{trn} \mathrm{L}-\operatorname{trn} \mathrm{F}$ and $m a t \mathrm{~K}$, the $\operatorname{trn} \mathrm{S}-\operatorname{trn} \mathrm{G}$ intergenic spacers and the rps 16 intron, as well as the ITS region of the nuclear genome. These regions have proved to be informative to infer the phylogenetic relationships in Loasoideae (Weigend et al., 2004; Hufford et al., 2005; Weigend \& Gottschling, 2006; Acuña et al., 2017). The amplification and sequencing protocols employed for the majority of samples follows Acuña et al. (2017). We generated new sequences for Loasa acaulis and Grausa lateritia using the following cycling conditions for all regions: initial denaturation of $95^{\circ} \mathrm{C}$ for $5 \mathrm{~min} ; 35$ cycles at $95^{\circ} \mathrm{C}$ for $1 \mathrm{~min}$, a specific annealing temperature for 1 $\min \left(52^{\circ} \mathrm{C}\right.$ for $\operatorname{trn} \mathrm{L}-\operatorname{trn} \mathrm{F}, 50^{\circ} \mathrm{C}$ for $\operatorname{trnS}$ - $\operatorname{trn} \mathrm{G}$ and mat $\mathrm{K}, 55^{\circ} \mathrm{C}$ for $r p s 16$ and ITS), $72^{\circ} \mathrm{C}$ for $1 \mathrm{~min}$; and a final elongation period of $72^{\circ}$ for $15 \mathrm{~min}$. Sanger sequencing was performed using the ABI PRISM 3100 Genetic Analyzer (Applied Biosystems ${ }^{\mathrm{TM}}$ ).

Sequences were mostly assembled in Geneious v. 8.0.1 (Kearse et al., 2012) using the default De Novo assembly settings. The assembled sequences were aligned in Mafft v. 7 (Katoh \& Standley, 2013). For the plastid sequences we used the G-INS-1 option. For the ITS sequences we used the Q-INS-I option, recommended by Chomicki \& Renner (2015). 
Manual adjustments were done using PhyDE v. 0.9971 (Müller et al., 2010). The aligned matrices were submitted to TreeBase under the study numbers TB2: S26212 (ITS) and TB2: S26262 (plastid).

Phylogenetic reconstructions were carried out employing Maximum Likelihood (ML; Felsenstein, 1981) in RAxML v. 8.1.X (Stamatakis, 2014), included in RAxMLGUI v. 1.5b1 (Silvestro \& Michalak, 2012), and Bayesian Inference (BI; Mau et al., 1999), conducted in MrBayes 3.2.6 (Huelsenbeck \& Ronquist, 2001) on the CIPRES Science Gateway (Miller et al., 2010). FindModel (available from http://hcv.lanl.gov/content/sequence/ findmodel/findmodel.html), which implements Posada \& Crandall's (2001) Modeltest, selected GTR+Gamma as the substitution model that best fits all markers. Each marker was first analyzed separately. In the absence of topological conflict [defined as incongruence of topologies in nodes with bootstrap support $(\mathrm{BS}) \geq 75$ ] the plastid markers were combined. We found topological conflict between the ITS and the combined plastid trees in four nodes [two nodes in Caiophora, one in Pinnasa and one in Loasa Adans. ser. Macrospermae] so, the datasets were not combined. Both ML and BI analyses were then run independently for the combined plastid dataset (partitions unlinked) and for ITS. The statistical support for the nodes was assessed by 1000 ML bootstrap replicates. The BI were conducted with four independent runs with one cold and three heated chains; the Markov chain had a length of 10 million generations, sampled every 1000 generations. After convergence was assessed in Tracer 1.5 (Rambaut \& Drummond, 2007), the first 2.5 million generations were discarded as burn-in. Support was assessed as follows: Low $=$ BS: $<75$, Posterior Probability (PP): $<0.90$; Moderate $=$ BS: $\geq 75-<90$, PP: $\geq 0.90-<0.95$; High $=$ BS: $\geq 90$, PP: $\geq 0.95$.

\section{RESULTS AND DISCUSSION}

Plants corresponding to Loasa acaulis are found in Conguillío National Park, and resemble previously collected material deposited in CONC, E, and SGO from the same locality. Additionally, these specimens agree with the extant type material [C. Rahmer s.n. (SGO000003372, SGO000003373, F Neg No.10173)] and the protologue (Philippi, 1893) for
Blumenbachia acaulis. Collections of acaulescent, 3-5 leaflet-leaved, white-flowered "Loasas" show existence of additional populations of $L$. acaulis in the province of Biobío, Chile, and also in the Argentinean departments of Aluminé, Norquín, and Lácar all within the province of Neuquén. Although specimens of $L$. acaulis were collected in Argentina at least as far back as 1926 (Comber 542) no previous publication reported the unequivocal presence of this species in the country until now.

The decision of the synonymization, might likely have been the result of few collections of Loasa acaulis available in herbaria, the erroneous misconception of it having red flowers (Urban \& Gilg, 1900; Reiche, 1901), as well as the fact that some of the most striking differences between the two taxa are less obvious in dry specimens. Both species indeed show a similar habit and are found in similar habitats. They are perennial, acaulescent herbs adapted to open habitats above the treeline, at high altitudes in the Southern Andes. The leaves of L. acaulis and $G$. lateritia are also very similar to each other and quite distinct from the rest of species in Loasaceae. They differ from other Loasaceae by having long petioles, short rachises and few (3-5), crenate-margined, broadly-elliptical to subcircular-outline (almost as long as wide) leaflets. Stems are subterranean, slender, and with short internodes. Both species present erect flowers. Characters related to flower morphology are particularly useful in the identification of $L$. acaulis and its discrimination from G. lateritia. Flowers of G. lateritia present a more closed corolla with semierect to erect petals compared to the open, spreading corollas with horizontal petals of $L$. acaulis. The former has brick-red imbricate petals with broad, rounded and overlapping basal portions, while the latter has white-greenish petals with a flat and conspicuously narrow nail. Nectar scales also present notable differences and can be used for identification (Figs. 1 and 2). The nectar scales of G. lateritia are red and proportionally wider (being almost as long as wide) than the white scales of $L$. acaulis (about twice as long as wide). The dorsal threads of the nectar scales in $G$. lateritia are attached near the middle of the back of the scale, while in L. acaulis they are attached closer to the distal end of the scale. Based on these results the authors are confident in rejecting previous synonymization and treating $L$. acaulis and G. lateritia as two different species. 
In the species protologue $L$. acaulis was placed into Blumenbachia (Philippi, 1893), however this was incorrect, as twisted fruits are a synapomorphy for Blumenbachia (Weigend et al., 2004; Henning et al., 2015; Acuña et al., 2017), and are absent in $L$. acaulis. Floral scales of Blumenbachia lack a double arch and have dorsal threads attached to the proximal (basal) third of the scale. In comparison, L. acaulis has a distinct double arch, and dorsal threads that are attached distally on the back of the scale. The subsequent decision of Urban \& Gilg (1900) to place it in Loasa cannot be supported either, as L. acaulis lacks stinging trichomes, has compound leaves, and erect flowers. All of these traits are not found in any of the known species in Loasa (Acuña et al., 2017).

SEM analyses revealed that the seeds of Loasa acaulis show the most typical pattern described by Weigend et al. (2005) for the SAL clade. Southern Andean Loasa seeds consist of deeply pitted testas with smooth outer periclinal walls (that are absent/ break apart in mature seeds), in addition to secondary sculpturing. The seeds of $L$. acaulis appear to have a terminal hilum, as opposed to Loasa s.str. which presents a subterminal or lateral hilum. Likewise, there are no seed testa undulations, apical or longitudinal wings that characterize the different sections of Blumenbachia (Weigend et al. 2005). Incomplete fenestration found by Weigend et al. (2005) in G. micrantha (type for Grausa) was not found in the seeds of L. acaulis, nor in Grausa lateritia. Similar to the seeds of $G$. lateritia, the seeds of $L$. acaulis present total fenestration, and lack of any other morphological derivation. A hilar cone is present sometimes in L. acaulis and G. lateritia, but it is always reduced and inconspicuous in the former and neither taxon has the cone as fully developed as found with other Grausa.

Relationships inferred from morphological evidence are reinforced by the molecular analyses for both plastid and nuclear loci. The combined plastid dataset contained 6459 aligned positions (3361 distinct alignment patterns) with a $26.03 \%$ gaps and undetermined characters. The ITS dataset contained 863 aligned positions ( 647 distinct alignment patterns) with a $31.80 \%$ gaps and undetermined characters. The topologies for the ML and BI trees for each genome (plastid vs nuclear) had no significant topological differences (Fig. 3). The sister relationship between $L$. acaulis and $G$. lateritia is retrieved with very high support (Plastid \& ITS: $\mathrm{BS}=100, \mathrm{PP}=1.00$ ). These two species are in turn sister (Plastid: $\mathrm{BS}=100$, $\mathrm{PP}=1.00$; ITS: $\mathrm{BS}=90, \mathrm{PP}=1.00)$ to . gayana . Along with $G$. micrantha, these four species constitute a strongly supported clade (Plastid: $\mathrm{BS}=100$, $\mathrm{PP}=1.00$; ITS: $\mathrm{BS}=94, \mathrm{PP}=1.00$ ), and are sister to either Pinnasa (ITS, with low support, $\mathrm{BS}=58$, $\mathrm{PP}=0.56)$ or to Pinnasa + Scyphanthus + Caiophora (Plastid, with high support, $\mathrm{BS}=100, \mathrm{PP}=1.00$ ). Placement of L. acaulis within Grausa appears robust and including it within Loasa or Blumenbachia is not supported (Fig. 3). Based on these results we are confident in including L. acaulis in Grausa.

\section{Artificial key to Grausa}

1. Plants with subterranean stems and short internodes; flowers erect; found in high-Andean habitats usually above the treeline 2

1. Plants with winding aerial stems and long internodes (at least in mature plants); flowers pendant; found in low elevation habitats below the treeline

2(1). Petals red with a poorly differentiated broad claw, nectar scales red, almost as long as wide ...... Grausa lateritia 2. Petals greenish white with a well differentiated narrow claw, nectar scales white, ca. double as long as wide ......"Loasa" acaulis 3(1). Leaves sagittate G. sagittata

3. Leaves tri- or palmately-lobed to trifoliolate or palmately compound 4 4(3). Petals with serrate margins (proximally on the limb); dorsal threads of the nectar scale much shorter than the nectar scale; capsules straight, mature capsules longer than wide G. micrantha 4. Petals with entire (sometimes undulate) margins; dorsal threads of the nectar scale aprox. as long or longer than the nectar scale; capsules straight or basally curved, but if straight, the largest wider than long to aprox. as long as wide .................. 5 5(4). Nectar scales with two flaps on the back between the dorsal threads; dorsal threads ribbon-like (dorsoventrally flattened); capsules straight, wider than long to aprox. as long as wide, semisuperior G. martini 5. Nectar scales without two flaps on the back between the dorsal threads; dorsal threads filiform; capsules basally curved, longer than wide, inferior G. gayana 

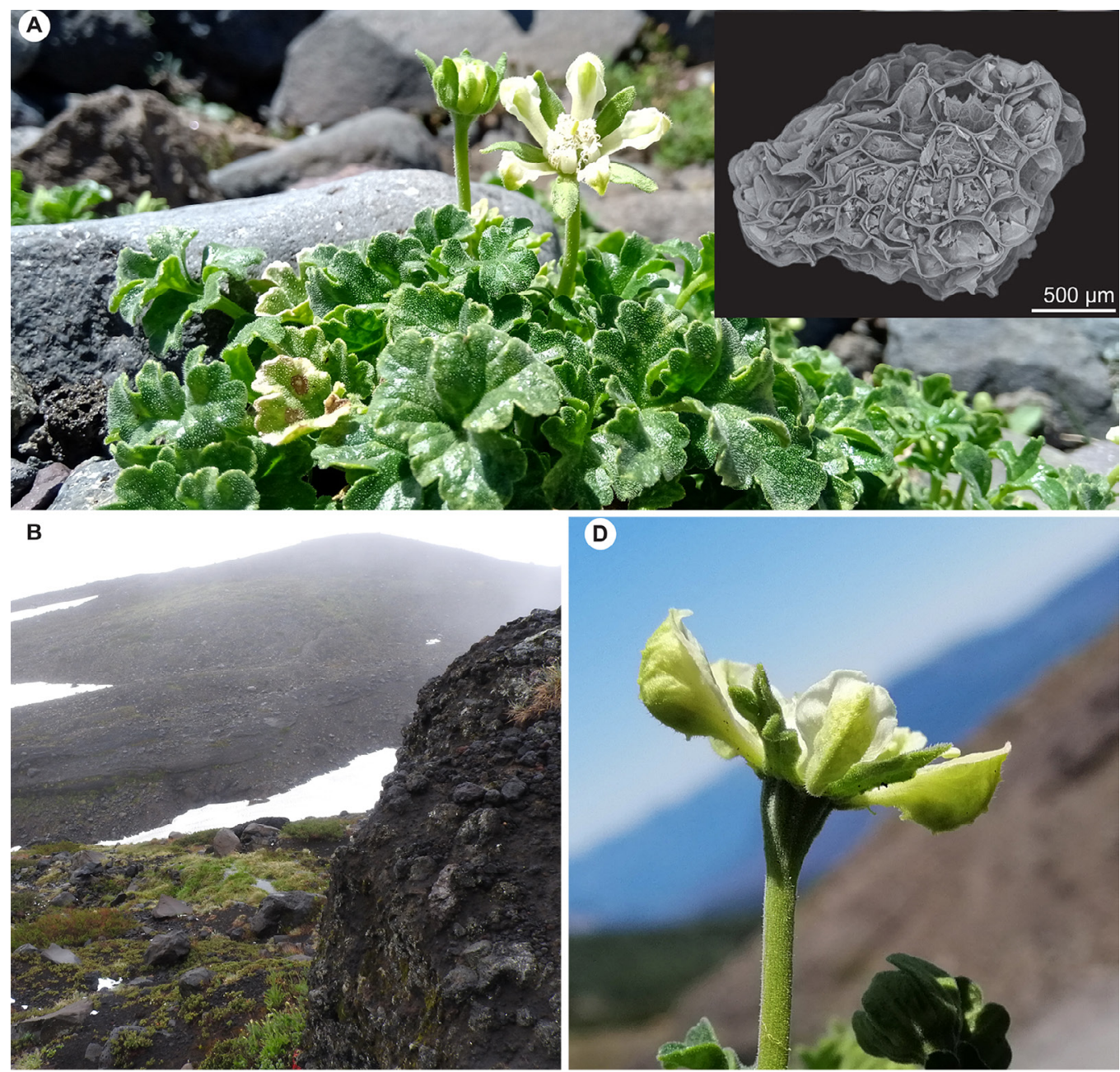

(D)
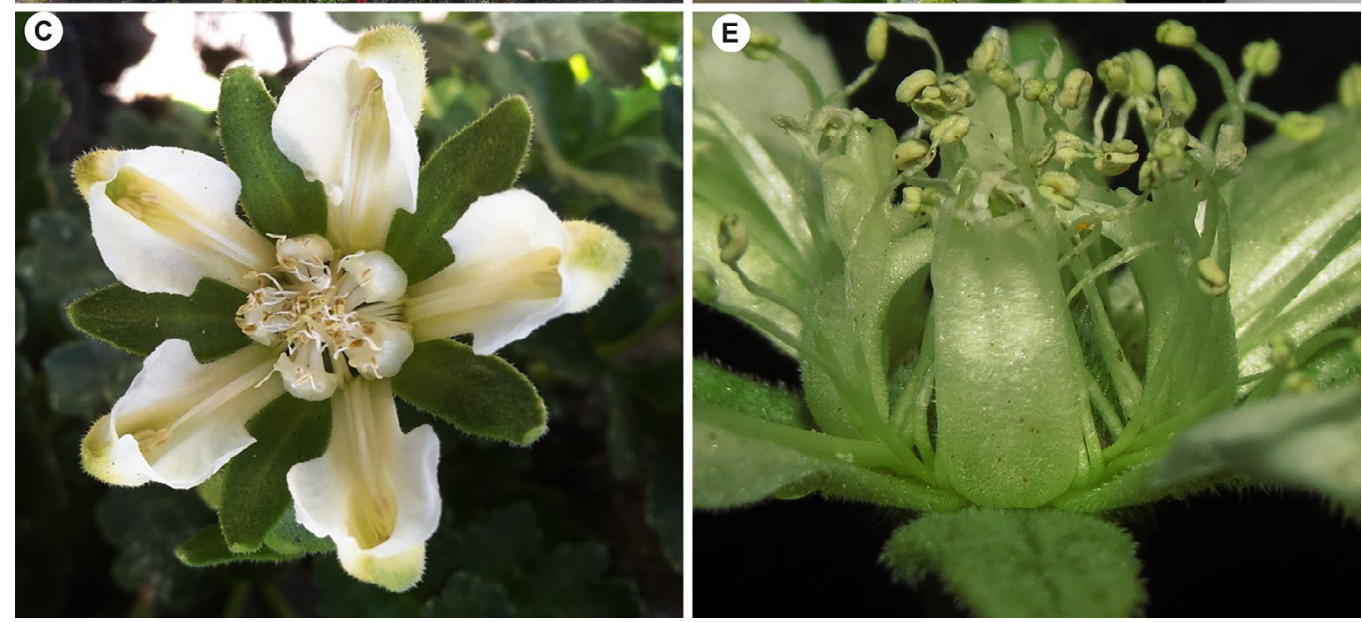

Fig. 1. Loasa acaulis. A, habit (L. Santilli), inset: SEM micrograph of seed. B, habitat in Parque Nacional Conguillío (January 2020, R. Acuña). C, flower during middle male phase, notice the conspicuous and well differentiated narrow claw of the petals (L. Santilli). D, flower, lateral view, notice the spread petals and narrow sepals (L. Santilli). E, nectar scales of a late male phase flower (L. Santilli). Color version at http://www.ojs.darwin.edu.ar/index.php/darwiniana/article/view/880/1185 

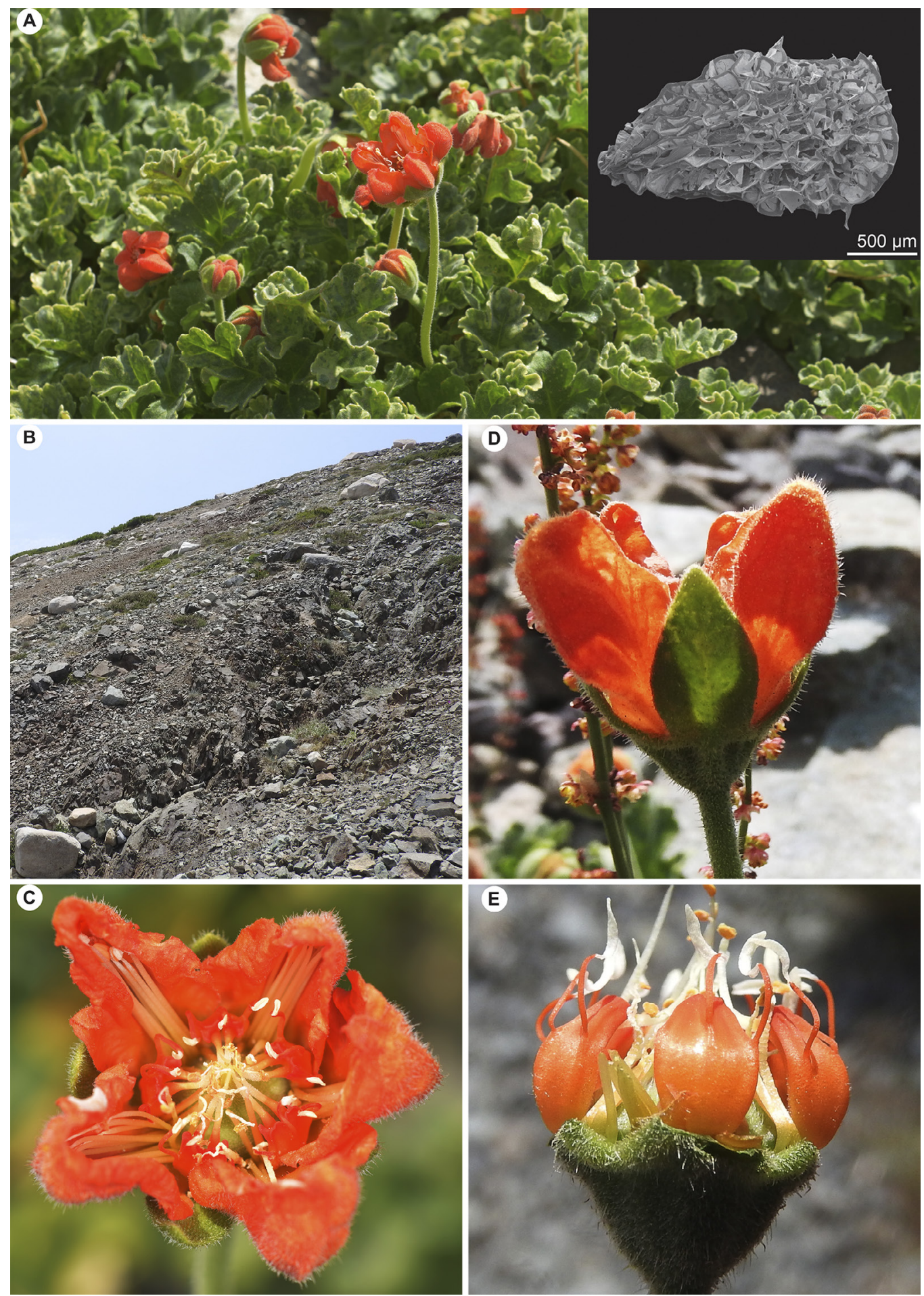

Fig. 2. Grausa lateritia. A, habit (D. Cohen), inset: SEM micrograph of seed. B, habitat in Reserva Nacional Altos de Lircay (January 2020, R. Acuña). C, flower during early male phase, notice the inconspicuous claw and broad petal bases (D. Cohen). D, flower, lateral view, notice the semi-erect petals and ovoid sepals (R. Acuña). E, nectar scales of an early male phase flower (R. Acuña). Color version at http://www.ojs.darwin.edu.ar/index.php/darwiniana/article/view/880/1185 


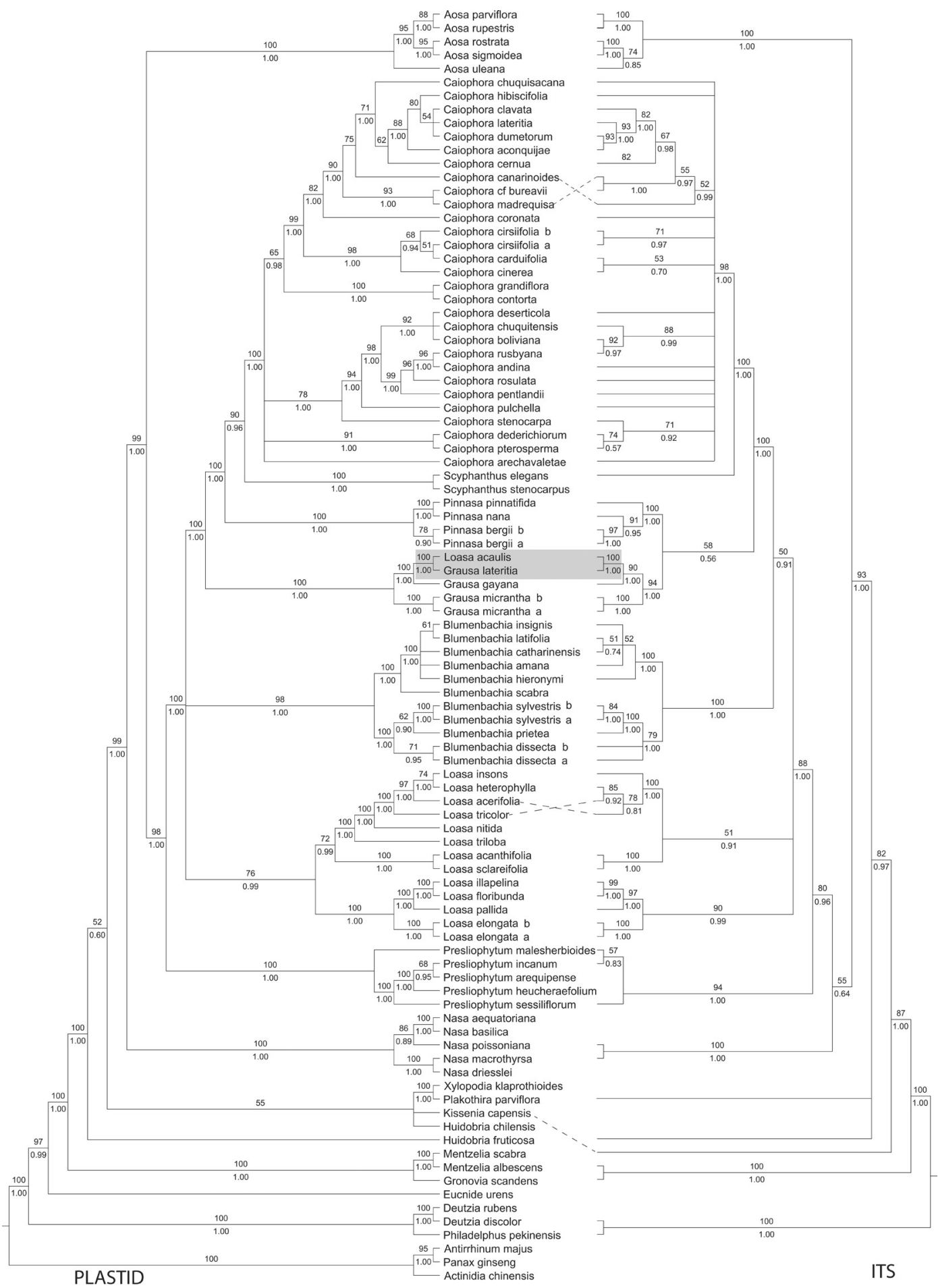

Fig. 3. Maximum likelihood trees focusing on the South Andean Loasas, highlighting Loasa acaulis and Grausa lateritia (grey rectangle). Left: Concatenated plastid marker dataset tree (trnL-trnF, matK, trnS-trnG, rps 16). Right: ITS dataset tree. The values for Bootstrap Support under Maximum Likelihood and Bayesian Posterior Probabilities are above and below the respective branch (values below 50 and 0.5 , respectively, are not shown). Dashed lines link the names on the center column to the ITS tree where it was not possible for straight horizontal lines. 


\section{TAXONOMIC TREATMENT}

Grausa acaulis (Phil.) L. Santilli, D.H. Cohen \& R.H. Acuña, comb. nov. $\equiv$ Blumenbachia acaulis Phil. in Anales Univ. Chile 85: 17. 1893. 三 Loasa acaulis (Phil.) Urb. \& Gilg in Nova Acta Acad. Caes. Leop.-Carol. German. Nat. Cur. 76: 186. 1900. TYPE: Chile, VIII Región del Biobío, Prov. Biobío, Trapa in Araucania, II-1887, C. Rahmer s.n. (lectotype, SGO barcode SGO000003372! designated here; isolectotype: SGO barcode SGO000003373!).

Herb to ca $17 \mathrm{~cm}$ tall (including leaves, flowers and fruits). Stems mostly subterranean to ca. $2 \mathrm{~mm}$ diam. Stem epidermis with abundant glochidiate trichomes, and more sparse scabrid ones. Root system unknown. Leaves opposite, petiole to $103 \mathrm{~mm}$, with indumentum similar to the stem but usually denser, lamina ternately, or more rarely pinnately, divided, margin crenate, blade segments trilobed with the terminal segment trilobed, adaxially covered mostly in scabrid trichomes, with shorter and often inconspicuous glochidiate trichomes, abaxially covered mostly in glochidiate trichomes with scabrid trichomes on the veins, lateral blade segments 12-24 mm x 8-20 mm, usually smaller than the terminal segment, petiolules 1-6 mm, terminal segment $13-30 \times 12-37 \mathrm{~mm}$, rachis 2-20 mm. Pedicels 35-140 mm, indumentum similar to that of the emerging portions of the stems and petioles, flowers erect or slightly bent with marked asymmetrical ovary during anthesis, sepals five, oblong with apex acute 6-8 x 2-4 mm, margins entire, upperside covered in scabrid trichomes, underside covered in both scabrid and glochidiate trichomes. Petals five, $10-13 \mathrm{~mm}$, white with the abaxial side greenish along the middle vein, the adaxial side pilose, the abaxial side with scabrid and glochidiate trichomes, the nail significantly narrower than the limb and distinct, the limb, boat-shaped with margins flat and entire, with three conspicuous veins in the lower half, and one in the upper half. Floral scales five, fourlobed at the apex, $4 \times 2 \mathrm{~mm}$, lobes approx. 1/6 of the floral scale, white, slightly heeled, very shortly papillose at the base, glabrous in the inner side and with sparse scabrid trichomes on the outer side, dorsal threads three, almost equal sized, $2,5-3 \mathrm{~mm}$, attached just below the base of the lobes of the floral scale, with the tips expanded and anther like. Staminodes two per scale, 6-7 mm, sinuous, the base flattened and with papillose margins, tapering into a long papillose filament. Stamens hidden into the petals, ca 50-100 per flower, filaments 6-9 $\mathrm{mm}$. Ovary inferior, roof covered in glochidiate and scabrid trichomes, outer surface densely covered in scabrid trichomes, style to $3 \mathrm{~mm}$ with ridges in the terminal region and onto the stigma, glabrous in the upper half, pubescent and covered in scabrid trichomes underneath. Placentae parietal, 5. Fruits straight, inferior capsules, 12-25 mm, 11-17 mm wide at calyx insertion, dehiscence apical, through 5 valves. Seeds numerous, $1.8-2 \times 1.2-1.5 \mathrm{~mm}$, with a deeply pitted reticulate testa, brown, with high anticlinal walls and a terminal hilum often protracted into an inconspicuous small cone, anticlinal walls with total fenestration. Karyotype unknown. (Fig. 1.)

Comments. The protologue cites a single collector (C. Rahmer), collection locality (Trapatrapa) and year of collection (1887). Two specimens found in SGO (SGO barcode SGO000003372 and SGO barcode SGO000003373) agree with the protologue description and collection details. Both were also annotated by R.A. Philippi. SGO000003372 was selected as the lectotype because it contains the most complete specimen. This lectotypification is in agreement with article 9.3 of Turland et al. (2018).

For many years it was thought that Grausa acaulis was a Chilean endemic (Sleumer, 1955), while Argentinean specimens that conformed to this species, were considered Loasa lateritia (Sleumer, 1955; Pérez-Moreau \& Crespo, 1988). Grausa acaulis is allopatric to G. lateritia, with no known intermediate specimens between both species. This species has potential as an ornamental due to its showy flowers and lack of stinging trichomes, however due to its adaptations to alpine habitats it may be difficult to raise from seed in most environments. 
Etymology. The epithet refers to the lack of a developed aerial stem.

Distribution and habitat. Endemic to the South Andes (Fig. 4.) of Chile (Araucanía and Biobío regions), and Argentina (Province of Neuquén), prefers to grow among rocks on open volcanic ash slopes at high altitude (1200-2500 m).

Phenology and pollination ecology. Flowering from December to March. Fruiting from February to March. Flower visitors unknown.

Associate species. Blumenbachia prietea Gay, Caltha sagittata Cav., Polystichum andinum Phil, Pozoa coriacea Lag., Nassauvia sp., Senecio sp., Phacelia secunda J.F. Gmel., Ourisia fragrans Phil., Oxalis adenophylla Gillies ex Hook. \& Arn., Chaetanthera villosa D. Don, Baccharis magellanica (Lam.) Pers., Epilobium australe Poepp. \& Hausskn. ex Hausskn., Gaultheria nubigena (Phil.) B.L. Burtt \& Sleumer, Gaultheria poeppigii DC., Leucheria papillosa Cabrera, Leucheria magna Phil., Calceolaria filicaulis Clos, Adesmia longipes Phil.

Similar species. For differences from Grausa lateritia, refer to the second paragraph of Results and Discussion above. Blumenbachia species (in particular B. prietea) have stinging trichomes, non-erect (deflexed/pendent to horizontal) flowers, nectar scales without a double arc, dorsal threads attached near the base of the scale, twisted fruits with longitudinal dehiscence and seeds with a very different morphology but always with persistent outer periclinal walls and equatorial undulations.

Caiophora nivalis Lillo and C. pulchella Urb. \& Gilg have stinging hairs, diminutive sepals, yellow to orange nectar scales that contrast with their white corollas and, in the case of $C$. pulchella, mostly superior capsules. Additionally, C. nivalis is only found in NW Argentina and no further south than Catamarca (Slanis et al., 2016).

White flowered Pinnasa species have more than 5 pinnae/segments per mature leaf, petals with laciniate margins, nectar scales with a more strongly defined double arc and often with orange markings.

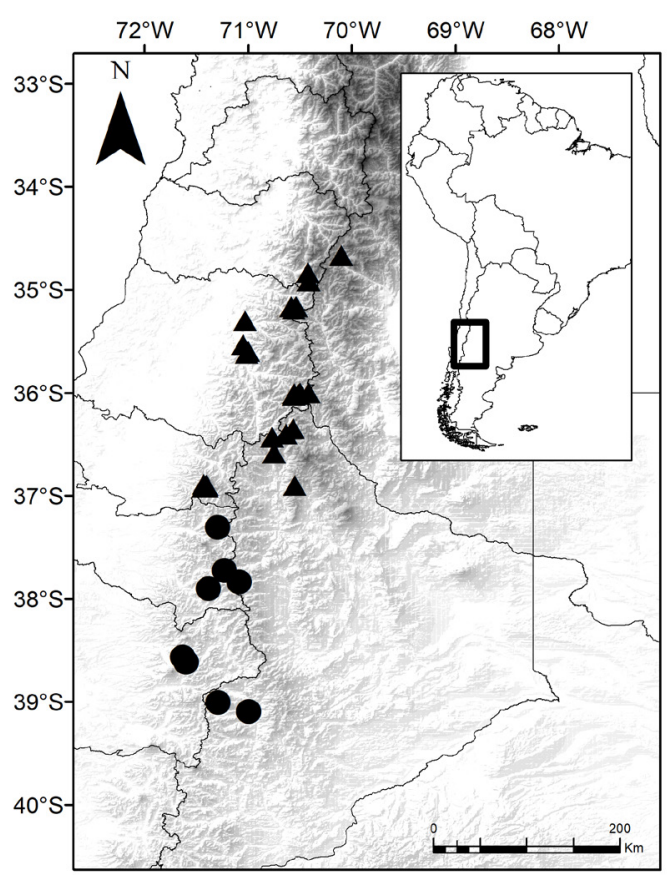

Fig. 4. Distribution map of Grausa lateritia and Grausa acaulis. Triangles correspond to G. lateritia and circles to $G$. acaulis

White flowered Loasa have stinging trichomes, simple (albeit sometimes deeply pinnatisect) leaves, non-erect (deflexed/pendent to horizontal) flowers, nectar scales with yellow, orange or red markings, and seeds with a subterminal hilum.

Conservation status. G. acaulis can be considered as Vulnerable (VU) under the IUCN categories and criteria Blab(iii). The criterion B1 was selected because its extent of occurrence is $<20,000 \mathrm{~km}^{2}\left(8,709.23 \mathrm{~km}^{2}\right)$. The criterion "a" was selected because it is known to exist at less than 10 locations. The criterion "b(iii)" was selected because there is a projected decline in the area, extent and quality of habitat. Global warming represents a threat to high Andean plants, whose habitat is strictly connected to snow and ice dynamics. The situation in Chile is aggravated by the fact that maximum temperatures have risen sharply over the last 10 years, and this increase is especially pronounced at elevations above $1,000 \mathrm{~m}$ a.s.l. 
In the Andean foothills of Central Chile, the elevation of the snow-line has gradually increased, with subsequent reduction of snow cover and a drop in maximum water flow rates from melting snow and ice (Garreaud, 2015; Rojas et al., 2019). This species can be found in protected areas, particularly Parque Nacional Conguillío (Chile), Reserva Nacional Ralco (Chile), and Parque Nacional Lanín (Argentina).

\section{Additional specimens examined}

ARGENTINA: Province Neuquén, Dept. Norquín: Copahue, más arriba de los Baños, 2000 m, 15.III.1969, J. Diem 3355 (BAB), Copahue, en laderas al pie de rocas, 1970 m, 13.I.1963, F. Roig \& A. Ruiz 4366/RL22424 (BAB); Dept. Aluminé: Norquinco, Pulmari, ca. 1200 m, 12.II.1926, $H$. Comber 542 (E); CHILE: Region Biobío, Prov. Biobío: Antuco, Sierra de Polcura über der Laguna Laja, 2500 m, 03.II.1968, O. Zöllner 2430 (L), Reserva Nacional Ralco, sobre límite arbóreo, faldeos Volcán Callaqui, 1735 m, II.2002, Mihoc et al. 4348 (CONC); Region Araucanía, Prov. unknown: II.1888, R. Philippi s.n. (K); Prov. Malleco, Curacautín, Termas Río Blanco, 1300 m, 15.II.1936, G. Montero 2704 (CONC, US), Río Blanco, 1100 m, 28.XII.1952, H. Schwabe 434 (CONC), Cordillera de los Andes, PN Conguillío: slopes of Sierra Nevada trail, 1650 m, 18.I.2013, T. Christian et al. 226 (E), beginning of travesía Río Blanco path, 1710 m, 26.I.2004, P. Brownless et al. DCI 995 (E, SGO), sector de Sierra Nevada, al final del sendero a Sierra Nevada, 05.III.2005, L. Flores s.n. (SGO), Sierra Nevada, $1680 \mathrm{~m}$, 17.III.2006, R. Hildebrand-Vogel \& L. Flores s.n. (SGO). Sierra Nevada, 1680 m, 2.II.2020, L. Santilli \& N. Lavandero 200220 (SGO).

Grausa lateritia (Gillies ex Arn.) Weigend \& R.H. Acuña in Taxon 66: 374. 2017. $\equiv$ Loasa lateritia Gillies ex Arn., Edinburgh J. Nat. Geogr. Sci. 3: 275. 1831. TYPE: Chile, Andes of Chile, 1827, Gillies s.n. (lectotype, E barcode E00158250! designated by Acuña et al. 2017, Taxon 66: 374).

Herb to ca $30 \mathrm{~cm}$ tall (including leaves, flowers and fruits). Stems mostly subterranean to ca. $3 \mathrm{~mm}$ diam. Stem epidermis with abundant glochidiate trichomes, and more sparse scabrid ones (these structures are very indistinct and eroded in the subterranean portion of the stems). Root system unknown. Leaves opposite, petiole to $102 \mathrm{~mm}$, with indumentum similar to the stem but usually denser, lamina usually ternately or, more rarely, pinnately divided, blade segments lobed to pinnatifid, adaxially covered mostly in scabrid trichomes, and scattered shorter and often inconspicuous glochidiate trichomes, abaxially covered mostly in glochidiate trichomes with scabrid trichomes mostly restricted to the veins, lateral blade segments $19-27$ x 17-25 mm, usually smaller than the terminal segment, petiolules to $5 \mathrm{~mm}$, terminal segment 28-46 x 24-36 mm. Pedicels 140-160 $\mathrm{mm}$, lenghtening (200-216 mm) after anthesis, indumentum similar to that of the stems and petioles. Sepals (calyx lobes) five, triangular 7-9 × $3 \mathrm{~mm}$, with 3 conspicuous veins, margins entire, adaxially covered in scabrid trichomes, abaxially covered with both scabrid and glochidiate trichomes. Petals five, $12-17 \mathrm{~mm}$, erect, deeply cymbiform, margins flat, entire, brick red to orange, the adaxial surface glabrescent to papilose, the abaxial side with scabrid and glochidiate trichomes. Floral scales five, $4 \times 3 \mathrm{~mm}$, red or orange, slightly keeled, very shortly papillose at the base, with a poorly developed neck rim, dorsal threads three, subequal in length, $4 \mathrm{~mm}$, papillose, attached just above the middle of the back of the nectar scale, with cream to white, expanded and sterile anther-like apices. Staminodes two per scale, $8 \mathrm{~mm}$, sinuous, the base flattened and with distinct papillose margins, from the base to ca. $30 \%$ of the length towards the tip, then thickened into a knob, beyond the knob tapering into a long papillose filament. Stamens ca 50-100 per flower, filaments $5-10 \mathrm{~mm}$. Style to $10 \mathrm{~mm}$, with 5-6 ridges in the terminal region and extending onto the stigma, glabrous in the terminal third, covered in scabrid trichomes proximally. Ovary inferior, roof covered in glochidiate and scabrid trichomes, outer surface (calyx) with similar, dense indumentum. Placentae five. Fruits inferior capsules, 20-25 x $17 \mathrm{~mm}$, obovoid to obconic, opening through 3-5 apical valves. Seeds 1.7-2 x $1.5 \mathrm{~mm}$, ovoid or conic, brown, with a deeply pitted reticulate testa, with high anticlinal walls, the hilum protracted into a small cone but this sometimes inconspicuous. $2 n=26$ (Grau 1988). (Fig. 2). 
Comments. This and Grausa acaulis are the only described species of the genus that are not vines, but instead are acaulescent plants adapted to life in open habitats above the tree line in the Southern Andes. It is also one of the most ornamental species of Loasaceae, because of its habit, beautiful brick red flowers, and lack of stinging trichomes. However, germination from seed seems to be difficult to achieve, probably due to adaptation to its native alpine habitat.

Etymology. The epithet refers to brick-red color of the corolla.

Distribution and habitat. Grausa lateritia is found between 1400 and $2500 \mathrm{~m}$ a.s.l. in Andean Central Chile and adjacent Argentina (Fig. 4). In Chile it occurs from O'Higgins to Nuble, while in Argentina it is known from Mendoza (Urban \& Gilg, 1900; Sleumer, 1955; Weigend et al., 2008) and Neuquén. This species prefers to grow in open, rocky areas, in high Andean habitats above the treeline.

Phenology and pollination ecology. This species is known to flower between January and April. Ants have been observed visiting the flowers probably to collect nectar (their effectiveness as actual pollinators has not been tested).

Associate species. Leucheria apiifolia Phil., Pozoa coriacea, Nastanthus sp., Leucheria glacialis (Poepp. ex Less.) Reiche, Acaena pinnatifida Ruiz \& Pav., Anemone multifida Poir., Perezia sp., Pinnasa pinnatifida (Gillies ex Arn.) Weigend \& R.H. Acuña, Vicia sp., Nassauvia revoluta D. Don., Phacelia secunda, Adesmia sp., Epilobium australe.

Similar species. Grausa lateritia is unlikely to be confused with other plants, due to its high Andean habitat in central Chile and Argentina, erect flowers, red petals and presence of staminodial nectar scale complexes.

For differences from Grausa acaulis, refer to the second paragraph of Results and Discussion above. Species of Pinnasa have more than 5 pinnae/segments per leaf and no known species has red petals.
Caiophora pulchella Urb. \& Gilg (endemic to Argentina) has stinging hairs, white corollas, and mostly superior capsules.

Caiophora lateritia Klotzsch has stinging trichomes, twining stems, twisted capsules and is allopatric, being known only from Southern Bolivia and Northwestern Argentina, no further south than Catamarca (Slanis et al., 2016). Specimens of $C$. lateritia are sometimes mislabeled as Loasa lateritia.

Species of Loasa have stinging hairs, simple leaves and usually white or yellow corollas. L. acanthifolia and L. sclareifolia Juss. may develop orange (both species) or red flowers ( $L$. acanthifolia e.g. from Nuble and Biobío), however these are large plants (sometimes over $1 \mathrm{~m}$ tall) with well developed aerial stems and are usually found at lower altitudes in forested, or historically forested, habitats.

Conservation status. G. lateritia can be considered as Vulnerable (VU) under the IUCN categories and criteria B1ab(iii). The criterion B1 was selected because its extent of occurrence is $<20.000 \mathrm{~km}^{2}\left(11.522,109 \mathrm{~km}^{2}\right)$. The criterion "a" was selected because it is known to exist at less than 10 locations. The criterion "b(iii)" was selected because there is a projected decline in the area, extent and quality of habitat. Global warming represents a threat to high Andean plants, whose habitat is strictly connected to snow and ice dynamics. The situation in Chile is worsen by the fact that maximum temperatures have risen sharply over the last 10 years, and this increase is especially pronounced at elevations above $1,000 \mathrm{~m}$ a.s.l. In the Andean foothills of Central Chile, the elevation of the snow-line has gradually increased, with subsequent reduction of snow cover and a drop in maximum water flow rates from melting snow and ice (Garreaud, 2015; Rojas et al., 2019). This species can be found in protected areas such as Reserva Nacional Altos de Lircay (Chile) and Reserva Nacional Río de los Cipreses (Chile) where it can be locally common.

\section{Additional specimens examined}

ARGENTINA: Province Mendoza, Dept. San Rafael: Cordillera al Sur del Rio Atuel, II.1897, J. R. Figueroa s.n. (CORD); Province Neuquén, 
Dept. Minas: Laguna Varvarco Campos, extremo $\mathrm{S}$ de la laguna, cañadón al $\mathrm{W}$, en pedregal, 14001850 m, 15.II.1985, R. Gómez \& R. Rossow 2829 (BAB), Paso del Macho, bajada hacia laguna, 2280 m, 26.I.1970, O. Boelcke et al. 13917 (BAB), Confluencia de los ríos Pichi-Neuquén y Neuquén, Cerro de las Yeguas, 23.I.1970, O. Boelcke et al. 13775 (BAB), Cajón de la Botica, 16.II.1985, R. Gómez \& R. Rossow 2850 (BAB); CHILE: Region Unknown: Andes of Chile, [1827], Gillies s.n. (E, GH, K), La Sepultura, s.d., Gillies s.n. (BM); Region O'Higgins, Prov. Cachapoal: Machalí, Medina, Río Cipreses, Vega Altoandina, fuera vega, $2604 \mathrm{~m}$, 3.II.2006, P. Saldivia \& B. Larraín 1649 (CONC), Reserva Nacional Río de Los Cipreses, Cascada frente de puente de nieve, 16.I.1984, G. Grua s.n. (EIF); Prov. Colchagua: Quebrada de Fray Carlos, Apr 1827, Gillies s.n. (BM), Cordillera de San Fernando, II.1843, V. Bustillos s.n. (SGO); Region Maule, Prov. Curicó: Los Imposibles, Mar 1827, Gillies s.n. (GH, K), Laguna de Teno, II.1967, F. Behn s.n. (CONC), orillas de la Laguna de Teno, 2500 m, 10.III.1967, C. Marticorena \& O. Matthei 930 (CONC, F), South facing slope of northern shore of Laguna de Teno, 2595 m, 05.III.2019, L. Santilli \& N. Lavandero 25 (SGO), Lago Teno - Tal umgebung des Embalse de Planchón, 2200-2500 m, 29.III.1975, J. Grau 1533 (M); Prov. Talca: Cordillera de Talca, s.d., $R$. Philippi s.n. (K), Laguna de Maule, ca. $2200 \mathrm{~m}$, I.1943, H. Behn s.n. (CONC), 2200 m, II.1950, V. Barros Herb. Gunckel 22164 (CONC), 2280 m, 20.I.1961, F. Schlegel 3532 (CONC), loose rocky screes, $2300 \mathrm{~m}$, 24.I.1990, M. Gardner et al. 4521 (CONC, E), entre Laguna del Maule y Paso Pehuenches, 13.II.1963, M. Ricardi et al. 968 (CONC), San Clemente, Valley west of Laguna del Maule, 2173 m, 22.II.2011, M. Gardner et al. 9 (BONN, E), Reserva Nacional Altos de Lircay, bajada a laguna del cerro Peine, 2100 m, 19.II.2006, N. Garcia 2921 (EIF), Alrededores de la Laguna Maule, 9.II.2007, Chiapella et al. 1692 (CORD), Alto de Vilches, 2250 m, 31.I.2000, Finot y Lopez 1850 (CONC), Laguna del Maule, South of access road, rocky peaks, $2350 \mathrm{~m}$, 25.I.1981, J. Grau 2891 (M), Turrieta, Cordillera de Talca, 19.II.1879, F. Philippi s.n. (SGO) Maule Andes, I.1862, H. Volckmann s.n. (SGO) Cordillera de Talca, II.1879, P. Ortega s.n. (SGO), Laguna del Maule, cerros detras del Refugio Deportivo, 2040 m, 18.I.1995, A, Marticorena et al. 184 (CONC); Region Nuble, Prov. Diguillín: Baños de Chillán, Nieblas, ca. 2000 m, III.1927, E. Werdermann 1342 (B, CONC, E, F, U, US), s.d., C. Deltor 2023, (CONC), II.1933, F. Jaffuel s.n. (CONC), Cordillera de Chillán, Valle de Las Nieblas, 2300 m, 25.I.1935, A. Pfister s.n. (CONC), 2000 m, I.1940, A. Pfister s.n. (CONC), Termas de Chillán, Valle de Las Nieblas, 2100 m, 27.II.1947, A. Pfister s.n. (CONC), Termas de Chillán, Cerro Pirigallo, ladera Oeste, $2000 \mathrm{~m}$, 1.III.1979, R. Rodríguez 1117 (CONC) Termas de Chillán, Cerro Pirigallo, cumbre, $2200 \mathrm{~m}$, 1.III.1979, R. Rodríguez 1114 (CONC), Cordillera de Chillán, Garganta del Diablo, frente al Refugio Aserradero, 1500 m, 13.III.1981, R. Rodríguez \& J. Arriagada 1354 (CONC), Baños de Chillán, 2100-2200 m, s.d., F. Pennell 12449 (F, SGO, US), Termas de Chillán, camino a cerro Pirigallo por sendero las Fumarolas, 2200 m, 19.II.2020, L. Santilli \& N. Lavandero 190220 (SGO), Nevados de Chillán, Übergang vom calle de las Nieblas zum Valle Aguas Calientes. Sudostl. des Volcan Chillán, 2300 m, 23.III.1975, J. Grau 1495 (M), Nevados de Chillán, Garganta del Diablo, Lava, 1900 m, 13.III.1981, J. Grau 3076 (M), Valle de las Nieblas, Cordillera de Chillán, I.1877, F. Philippi s.n. (SGO), Cordillera de Chillán, I.1860, R. Pearce s.n. (SGO).

\section{ACKNOWLEDGMENTS}

We thank Nicolás García from EIF, for the logistic help and for allowing us to study specimens under his care. Alicia Marticorena and Rosa Montero from CONC allowed us to study specimens under their care. Renee Fortunato and María Monsalvo from BAB sent us high quality images of specimens under their care. We also like to thank the curatorial staff at SGO, MERL, CORD and SI. Rosita Scherson from EIF for collaborating with the collection permits for this project. Nicolás Lavandero helped and accompanied us to the field. To the CONAF personnel. Gioconda Peralta, Fernanda Perez, Javiera Chinga, Maximilian Weigend and Hans-Jürgen Ensikat for the support provided with molecular and SEM work. Lorena Flores for donating her specimens. Funding was provided by the Alpine Garden Society and Rancho Santa Ana Botanic Garden. 


\section{BIBLIOGRAPHY}

Acuña, R.; S. Fließwasser, M. Ackermann, T. Henning, F. Luebert \& M. Weigend. 2017. Phylogenetic relationships and generic re-arrangements in "South Andean Loasas" (Loasaceae). Taxon 66: 365-378

Chomicki, G. \& S. S. Renner. 2015. Watermelon origin solved with molecular phylogenetics including Linnaean material: another example of museomics. New Phytologist 205: 526-532.

CONAF 2006. Plan de manejo Parque Nacional Coguillío. Documento de Trabajo 405. Corporación Nacional Forestal (CONAF), Santiago, Chile.

de la Barrera, F.; D. Moreira \& R. Bustamante. 2011. Efecto de un sendero sobre la comunidad de plantas nativas en la Reserva nacional Altos del Lircay (Region del Maule-VII-Chile). Chloris Chilensis 14(1).

Doyle, J. J. \& J. L. Doyle. 1987. A rapid DNA isolation procedure for small quantities of fresh leaf tissue. Phytochemical Bulletin 19: 11-15.

Felsenstein, J. 1981. Evolutionary trees from DNA sequences: a maximum likelihood approach. Journal of Molecular Evolution 17: 368-376.

Gajardo, R. 1983. Sistema básico de clasificación de la Vegetación Nativa Chilena. Ministerio de Agricultura. Corporación Nacional Forestal (CONAF). Universidad de Chile. 319

Garreaud, R. 2015. The 2010-2015 mega-drought: A lesson for the future. Center for Climate and Resilience ResearchUniversidad de Chile.

Grau, J. 1988. Chromosomenzahlen chilenischer Loasaceae. Mitteilungen der Botanischen Staatssammlung München 27: 7-14.

Henning, T.; S. Oliveira, C. Schlindwein \& M. Weigend. 2015. A new, narrowly endemic species of Blumenbachia (Loasaceae subfam. Loasoideae) from Brazil. Phytotaxa 236: 47-93.

Huelsenbeck, J. P. \& F. Ronquist. 2001. MRBAYES: Bayesian inference of phylogenetic trees. Bioinformatics 17: 754-755.

Hufford, L.; M. M. McMahon, R. O’Quinn \& M. E. Poston. 2005. A phylogenetic analysis of Loasaceae subfamily Loasoideae based on plastid DNA sequences. International Journal of Plant Sciences 166: 289-300.

Katoh, K. \& D. M. Standley. 2013. MAFFT multiple sequence alignment software version 7: improvements in performance and usability. Molecular Biology and Evolution 30: 772-780.

Kearse, M.; R. Moir, A. Wilson, S. Stones-Havas, M. Cheung, S. Sturrock, S. Buxton, A. Cooper, S. Markowitz, C. Duran, T. Thierer, B. Ashton, P. Meintjes \& A. Drummond. 2012. Geneious Basic: an integrated and extendable desktop software platform for the organization and analysis of sequence data. Bioinformatics 28: 1647-1649.
Marticorena, C. \& M. Quezada. 1985. Catálogo de la flora vascular de Chile. Gayana Botánica 42: 1-157.

Mau, B.; M. A. Newton \& B. Larget. 1999. Bayesian phylogenetic inference via Markov chain Monte Carlo methods. Biometrics 55: 1-12.

Miller, M. A.; W. Pfeiffer \& T. Schwartz. 2010. Creating the CIPRES Science Gateway for inference of large phylogenetic trees. In 2010 gateway computing environments workshop (GCE), pp. 1-8.

Müller, K.; J. Müller, C. Neinhuis \& D. Quandt. 2010. PhyDEPhylogenetic data editor, Version 0.9971. Program distributed by the authors. http: $\| w w w . p h y d e . d e$

Pérez-Moreau, R. L. \& S. Crespo. 1988. Loasaceae, in Correa, M. N. (ed.), Flora Patagónica. Vol. 8 (5), pp. 199-217. Buenos Aires, Colección Científica del Instituto Nacional de Tecnología Agropecuaria.

Pfanzelt, S.; J. Grau \& R. Rodríguez. 2008. A Vegetation Map of Nevados de Chillan Volcanic Complex, Bio-bío Region, Chile / Cartografia de Vegetación del Complejo Volcánico Nevados de Chillán, Región del Bio-bío, Chile. Gayana. Botanica 65: 209-219.

Philippi, R. A. 1893. Plantas nuevas chilenas de las familias Rosáceas, Onagrariáceas i demás familias del tomo II de Gay. Loáseas. Anales de la Universidad de Chile 85: 5-18.

Posada, D. \& K. A. Crandall. 2001. Selecting the best-fit model of nucleotide substitution. Systematic Biology 50: 580-601.

Rambaut, A. \& A. J. Drummond. 2007. Tracer v1. 5 Available from http://beast.bio.ed.ac.uk. Tracer (last accessed December 2019).

Reiche, K. 1901. Estudios críticos sobre la flora de Chile. 47. Familia Loasáceas. Anales de la Universidad de Chile 108: 707-751.

Rodríguez, R.; C. Marticorena, D. Alarcón, C. Baeza, L. Cavieres, V. L. Finot, N. Fuentes, A. Kiessling, M. Mihoc, A. Pauchard \& E. Ruiz. 2018. Catálogo de las plantas vasculares de Chile. Gayana Botánica 75: 1-430.

Rojas, M.; P. Aldunce, L. Farías, H. González, P. Marquet, J. C. Muñoz, R. Palma-Behnke, A. Stehr \& S. Vicuña (editores). 2019. Evidencia científica y cambio climático en Chile: Resumen para tomadores de decisiones. Santiago: Comité Cientifico COP25; Ministerio de Ciencia, Tecnología, Conocimiento e Innovación.

Rubio, C.; M. Saavedra, M. Cuellar, R. Diaz \& W. Quilhot. 2013. Epiphytic lichens of Conguillío National Park, southern Chile. Gayana Botanica 70: 66-81.

Silvestro, D. \& I. Michalak. 2012. raxmlGUI: a graphical front-end for RAxML. Organisms Diversity \& Evolution 12: 335-337.

Slanis, A. C.; M. C. Perea \& A. Grau. 2016. Revisión taxonómica del género Caiophora (Loasaceae) para Argentina: C. sleumerii una nueva especie. Darwiniana, nueva serie 4(2): 138-191. DOI: https://doi.org/10.14522/darwiniana.2016.42.685 
Sleumer, H. 1955. Die Loasaceen Argentiniens. Botanische Jahrbücher für Systematik, Pflanzengeschichte und Pflanzengeographie 76: 411-462.

Stamatakis, A. 2014. RAxML version 8: a tool for phylogenetic analysis and post-analysis of large phylogenies. Bioinformatics 30: 1312-1313.

Thiers, B. [continuously updated, accessed 2017]. Index Herbariorum: a global directory of public herbaria and associated staff. New York Botanical Garden's Virtual Herbarium; available from: http://sweetgum.nybg.org/ih/ (accessed Jul 2019).

Turland, N. J.; J. H. Wiersema, F. R. Barrie, W. Greuter, D. L. Hawksworth, P. S. Herendeen, S. Knapp, W. -H. Kusber, D. -Z. Li, K. Marhold, T. W. May, J. McNeill, A. M. Monro, J. Prado, M. J. Price \& G. F. Smith (eds.). 2018. International Code of Nomenclature for algae, fungi, and plants (Shenzhen Code) adopted by the Nineteenth International Botanical Congress Shenzhen, China, July 2017. Regnum Vegetabile 159. Glashütten: Koeltz Botanical Books. DOI: https://doi.org/10.12705/Code.2018

Urban, I. \& E. Gilg. 1900. Monographia Loasacearum. Nova Acta Academiae Caesareae Leopoldino-Carolinae Germanicae Naturae Curiosorum 76: 1-384 + 8 plates.
Weigend, M.; M. Gottschling, S. Hoot \& M. Ackermann. 2004. A preliminary phylogeny of Loasaceae subfam. Loasoideae (Angiospermae: Cornales) based on trnL (UAA) sequence data, with consequences for systematics and historical biogeography. Organisms Diversity and Evolution 4: 73-90.

Weigend, M.; A. Gröger \& M. Ackermann. 2005. The seeds of Loasaceae subfam. Loasoideae (Cornales) II: Seed morphology of "South Andean Loasas" (Loasa, Caiophora, Scyphanthus and Blumenbachia). Flora-Morphology, Distribution, Functional Ecology of Plants 200: 569-591.

Weigend, M. \& M. Gottschling. 2006. Evolution of funnel-revolver flowers and ornithophily in Nasa (Loasaceae). Plant Biology 8: 120-142.

Weigend, M.; J. Grau \& M. Ackermann. 2008. Loasaceae. In: Zuloaga, F.O.; O. Morrone \& M. J. Belgrano (eds.). Catálogo de las plantas vasculares del Cono Sur (Argentina, sur de Brasil, Chile, Paraguay y Uruguay). Monographs in Systematic Botany from the Missouri Botanical Garden 107: 2413-2424.

Zuloaga, F. O.; M. J. Belgrano \& C. A. Zanotti. 2019. Actualización del Catálogo de las Plantas Vasculares del Cono Sur. Darwiniana, nueva serie 7(2): 208-278. DOI: https://doi. org/10.14522/darwiniana.2019.72.861

Appendix. List of taxa sampled with their respective voucher specimen, geographic origins and GenBank accession numbers (trnL-trnF, matK, trnS-trnG, rps 16, ITS, respectively) for the sequences used in the molecular phylogenetic analyses. Sequences obtained for the present work are indicated with asterisks (*). Dashes (--) indicate missing data. Caiophora pulchella Urb. \& Gilg and Grausa micrantha (Poepp.) Weigend \& R.H.Acuña (b) Heibl 03-097, were misnamed as Caiophora nivalis Lillo and Loasa martini Phil. respectively in GenBank.

Actinidia chinensis Planch., KP297245.1, KP297245.1, KP297245.1, KP297245.1, KR819508.1; Antirrhinum majus L., AJ430929.1, AF051978.1, FR690224.1, GQ997033.1, AY591288.1; Aosa parviflora (Schrad. ex DC.) Weigend, Brazil, Grant 4650 (BSB), KY286967, KY286698, KY286877, KY286787, KY286615; Aosa rostrata (Urb.) Weigend, Brazil, Salino 3042 (M), KY286948, KY286679, KY286858, KY286768, KY286598; Aosa rupestris (Gardner) Weigend, Brazil, Weigend 7138 (BSB), KY286925, KY286657, KY286835, KY286745, KY286581; Aosa sigmoidea Weigend, Brazil, Guedes \& al. 10360 (ALCB), KY286995, KY286725, KY286905, KY286815, KY286639; Aosa uleana (Urb. \& Gilg) Weigend, Brazil, Joßberger 342 (BONN), KY286998, KY286728, KY286908, KY286818, KY286641; Blumenbachia amana T.Henning \& Weigend, Brazil, Acuña 1204 (BONN), KY287001, KY286731, KY286911, KY286821, KY286643; Blumenbachia catharinensis Urb. \& Gilg, Brazil, Trevisan 1723 (BONN), KY287006, KY286736, KY286916, KY286826, KY286648; Blumenbachia dissecta (a) (Hook. \& Arn.) Weigend \& Grau, Chile, Grau s.n. (M), KY286968, KY286699, KY286878, KY286788, KY286616; Blumenbachia dissecta (b) (Hook. \& Arn.) Weigend \& Grau, Argentina, Weigend \& al. 6816 (BRCO), KY286961, KY286692, KY286871, KY286781, KY286611; Blumenbachia hieronymi Urb., Germany (Cultivated), Ackermann 601 (BSB), KY286966, KY286697, KY286876, KY286786, KY286614; Blumenbachia insignis Schrad., Germany (Cultivated), Weigend 7475 (B), KY286964, KY286695, KY286874, KY286784, KY286613; Blumenbachia latifolia Cambess., Brazil, Schwabe s.n. (B), KY286949, KY286680, KY286859, KY286769, KY286599; Blumenbachia prietea Gay, Argentina, Weigend \& al. 6823 (BRCO), KY286963, KY286694, KY286873, KY286783, KY286612; Blumenbachia scabra (Miers) Urb., Brazil, Hatschbach 41572 (NY), KY286993, --, 
KY286903, KY286813, --; Blumenbachia sylvestris (a) Poepp., Argentina, Coccuci \& Sersic 4780 (CORD), KY286969, KY286700, KY286879, KY286789, KY286617; Blumenbachia sylvestris (b)Poepp., Argentina, Weigend \& al. 6807 (BRCO), KY286919, KY286651, KY286829, KY286739, KY286577; Caiophora aconquijae Sleumer, Argentina, Strelin s.n. (CORD), KY286974, KY286705, KY286884, KY286794, KY286622; Caiophora andina Urb. \& Gilg, Chile, Moreira \& Luebert 2379 (SGO), KY287005, KY286735, KY286915, KY286825, KY286647; Caiophora arechavaletae (Urb.) Urb., Brazil, Weigend 9330 (BSB), KY286970, KY286701, KY286880, KY286790, KY286618; Caiophora boliviana Urb. \& Gilg, Bolivia, Badcock 619 (K), KY286955, KY286686, KY286865, KY286775, KY286605; Caiophora canarinoides (Lenné \& K.Koch) Urb. \& Gilg, Peru, Ackermann 375 (BSB), KY286975, KY286706, KY286885, KY286795, KY286623; Caiophora carduifolia C.Presl, Peru, Ackermann 288 (BSB), KY286939, KY286671, KY286849, KY286759, KY286591; Caiophora cernua (Griseb.) Urb. \& Gilg ex Kurtz, Argentina, Ackermann 1100 (BONN), KY286972, KY286703, KY286882, KY286792, KY286620; Caiophora cf. buraeavii, Peru, Grant \& al. 10--4619 (BSB), KY286981, KY286712, KY286891, KY286801, KY286629; Caiophora chuquisacana Urb. \& Gilg, Bolivia, Ritter \& Wood 1498 (LPB), KY286982, KY286713, KY286892, KY286802, KY286630; Caiophora chuquitensis (Meyen) Urb. \& Gilg, Argentina, Ackermann 1101 (BONN), KY286983, KY286714, KY286893, KY286803, KY286631; Caiophora cinerea Urb. \& Gilg, Peru, Weigend \& al. 5715 (BSB), KY286953, KY286684, KY286863, KY286773, KY286603; Caiophora cirsiifolia (a) C. Pres1, Peru, Ackermann 610 (BSB), KY286984, KY286715, KY286894, KY286804, KY286632; Caiophora cirsiifolia (b) C. Presl, Peru, Henning \& Brokamp 16 (BSB), KY286971, KY286702, KY286881, KY286791, KY286619; Caiophora clavata Urb. \& Gilg, Argentina, Ackermann 1102 (BONN), KY287002, KY286732, KY286912, KY286822, KY286644; Caiophora contorta (Desr.) C.Presl, Ecuador, Weigend \& Brokamp 9110 (BSB), KY286985, KY286716, KY286895, KY286805, --; Caiophora coronata (Gillies ex Arn.) Hook. \& Arn., Argentina, Coccuci \& Sersic 4845 (CORD), KY286973, KY286704, KY286883, KY286793, KY286621; Caiophora dederichiorum Mark.Ackermann \& Weigend, Peru, Henning \& Schulz 19 (BSB), KY286977, KY286708, KY286887, KY286797, KY286625; Caiophora deserticola Weigend \& Mark.Ackermann, Chile, Muñoz-Schick 4296 (BSB), KY286952, KY286683, KY286862, KY286772, KY286602; Caiophora dumetorum Urb. \& Gilg, Argentina, Strelin 5481 (CORD), KY286986, KY286717, KY286896, KY286806, KY286633; Caiophora grandiflora (G.Don) Weigend \& Mark.Ackermann, Peru, Henning \& Brokamp 3 (BSB), KY286987, KY286718, KY286897, KY286807, --; Caiophora hibiscifolia (Griseb.) Urb. \& Gilg, Argentina, Ackermann 1103 (BONN), KY286988, KY286719, KY286898, KY286808, KY286634; Caiophora lateritia Klotzsch, Argentina, Ackermann 1104 (BONN), KY286989, KY286720, KY286899, KY286809, KY286635; Caiophora madrequisa Killip, Peru, Weigend \& Weigend 2000/440 (HUSA), KY286954, KY286685, KY286864, KY286774, KY286604; Caiophora pentlandii (Paxton ex Graham) G.Don ex Loudon., Peru, Ackermann 360 (BSB), KY286938, KY286670, KY286848, KY286758, KY286590; Caiophora pterosperma (Ruiz \& Pav. ex G.Don) Urb. \& Gilg, Peru, Weigend \& al. 5484 (BSB), KY286940, KY286672, KY286850, KY286760, KY286592; Caiophora pulchella Urb. \& Gilg, Argentina, Coccuci \& Sersic 4840 (CORD), KY286976, KY286707, KY286886, KY286796, KY286624; Caiophora rosulata (Wedd.) Urb. \& Gilg, Bolivia, Schlumpberger \& Brokamp 675 (BSB), KY287004, KY286734, KY286914, KY286824, KY286646; Caiophora rusbyana Urb. \& Gilg ex Rusby, Bolivia, Schlumpberger \& Brokamp 627 (BSB), KY287003, KY286733, KY286913, KY286823, KY286645; Caiophora stenocarpa Urb. \& Gilg, Peru, Ackermann \& al. 758 (BSB), KY286978, KY286709, KY286888, KY286798, KY286626; Deutzia discolor Hemsl., Germany (Cultivated), Weigend 5615 (BSB), KY286929, KY286661, KY286839, KY286749, KY286584; Deutzia rubens Rehder, Germany (Cultivated), Weigend 5613 (BSB), KY286928, KY286660, KY286838, KY286748, --; Ecunide urens Parry ex Coville, United States, Weigend 9153 (BSB), KY286996, KY286726, KY286906, KY286816, --; Grausa gayana (Urb. \& Gilg) Weigend \& R.H.Acuña, Chile, Weigend \& al. 7057 (BSB), KY286962, KY286693, KY286872, KY286782, MT393754*; Grausa lateritia (Gillies ex Arn.) Weigend \& R.H.Acuña, Chile, Santilli \& Lavandero 25 (SGO), MT268764*, MT274738*, MT268768*, MT268766*, MT232986; Grausa micrantha (a) (Poepp.) Weigend \& R.H.Acuña, Chile, Grau s.n. (M), KY286957, KY286688, KY286867, KY286777, KY286607; Grausa micrantha (b) (Poepp.) Weigend \& R.H.Acuña, Chile, Heibl 03-097 (not vouchered, only 
photograph of plant available), KY286990, KY286721, KY286900, KY286810, KY286636; Gronovia scandens L., Peru, Weigend \& al. 8522 (BSB), KY286997, KY286727, KY286907, KY286817, KY286640; Huidobria chilensis Gay, Chile, Ackermann 490 (BSB), KY286931, KY286663, KY286841, KY286751, --; Huidobria fruticosa Phil., Chile, Dillon 8034 (F), KY286932, KY286664, KY286842, KY286752, KY286586; Kissenia capensis R. Br. ex Harv. Endl., South Africa, Greuter 2167 (B), KY286944, KY286675, KY286854, KY286764, KY286596; Loasa acanthifolia Desr., Argentina, Weigend \& al. 6924 (BRCO), KY286959, KY286690, KY286869, KY286779, KY286609; Loasa acaulis (Phil.) Urb. \& Gilg, Chile, Brownless \& al. DCI 995 (SGO), MT268765*, MT274739*, MT268769*, MT268767*, MT248989*; Loasa acerifolia Dombey ex Juss., Argentina, Weigend \& al. 6848 (BRCO), KY286937, KY286669, KY286847, KY286757, KY286589; Loasa elongata (a) Hook. \& Arn., Chile, Ackermann 491 (BSB), KY286956, KY286687, KY286866, KY286776, KY286606; Loasa elongata (b) Hook. \& Arn., Chile, Weigend 9333 (BSB), KY287000, KY286730, KY286910, KY286820, KY286642; Loasa floribunda Hook. \& Arn., Chile, Weigend \& al. 5937 (BSB), KY286951, KY286682, KY286861, KY286771, KY286601; Loasa heterophylla Hook. \& Arn., Chile, Weigend \& al. 5920 (BSB), KY286930, KY286662, KY286840, KY286750, KY286585; Loasa illapelina Phil., Chile, Ackermann 519 (BSB), KY286950, KY286681, KY286860, KY286770, KY286600; Loasa insons Poepp., Chile, Ackermann 536 (BSB), KY286943, KY286674, KY286853, KY286763, KY286595; Loasa nitida Desr., Peru, Weigend \& al. 7346 (BSB), KY286936, KY286668, KY286846, KY286756, --; Loasa pallida Gillies ex Arn., Chile, Ackermann 1319 (BONN), KY286991, KY286722, KY286901, KY286811, KY286637; Loasa sclareifolia Juss., Chile, Weigend 8183 (B), KY286994, KY286724, KY286904, KY286814, KY286638; Loasa tricolor Ker Gawl., Chile, Luebert 3021 (B), KY286979, KY286710, KY286889, KY286799, KY286627; Loasa triloba Dombey ex Juss., Chile, Luebert \& Bidart 3014b (B), KY286999, KY286729, KY286909, KY286819, --; Mentzelia albescens (Gillies ex Arn.) Griseb., Argentina, Weigend \& al. 6865 (BRCO), KY286921, KY286653, KY286831, KY286741, KY286579; Mentzelia scabra Kunth, Peru, Weigend \& al. 98/470 (F), KY286922, KY286654, KY286832, KY286742, --; Nasa aequatoriana (Urb. \& Gilg) Weigend, Ecuador, Weigend \& Jaramillo 3937 (F), KY286947, KY286678, KY286857, KY286767, --; Nasa basilica T.Henning \& Weigend, Peru, Weigend \& al. 97/370 (F), KY286935, KY286667, KY286845, KY286755, --; Nasa driesslei Weigend, Peru, Henning \& Schneider 243 (BSB), KY286917, KY286649, KY286827, KY286737, --; Nasa macrothyrsa (Urb. \& Gilg) Weigend, Peru, Weigend \& al. 97/s.n. (M), KY286934, KY286666, KY286844, KY286754, KY286588; Nasa poissoniana (Urb. \& Gilg) Weigend, Peru, Weigend \& Weigend 00/208 (NY), KY286918, KY286650, KY286828, KY286738, KY286576; Panax ginseng C.A.Mey., KM088020.1, KM088020.1, KM088020.1, KM088020.1, FJ593178.1; Philadelphus pekinensis Rupr., Germany (Cultivated), Weigend 5614 (BSB), KY286927, KY286659, KY286837, KY286747, KY286583; Pinnasa bergii (a) (Hieron.) Weigend \& R.H.Acuña, Argentina, Weigend 6991 (BSB), KY286960, KY286691, KY286870, KY286780, KY286610; Pinnasa bergii (b) (Hieron.) Weigend \& R.H.Acuña, Argentina, Weigend 6800 (BRCO), KY286920, KY286652, KY286830, KY286740, KY286578; Pinnasa nana (Phil.) Weigend \& R.H.Acuña, Argentina, Weigend 7080 (BRCO), KY286980, KY286711, KY286890, KY286800, KY286628; Pinnasa pinnatifida (Gillies ex Arn.) Weigend \& R.H.Acuña, Argentina, Weigend \& al. 6880 (BRCO), KY286942, KY286673, KY286852, KY286762, KY286594; Plakothira parviflora J. Florence, France (Marquesas Is.), Weigend s.n. (BSB), KY286926, KY286658, KY286836, KY286746, KY286582; Presliophytum arequipense Weigend, Peru, Ortiz 121 (BONN), KY286965, KY286696, KY286875, KY286785, --; Presliophytum heucheraefolium (Killip) Weigend, Peru, Weigend 7368 (BSB), KY286946, KY286677, KY286856, KY286766, --; Presliophytum incanum (Graham) Weigend, Peru, Weigend \& Förther 97/848 (F), KY286924, KY286656, KY286834, KY286744, KY286580; Presliophytum malesherbioides (Phil.) R.H.Acuña \& Weigend, Chile, Wagenknecht 18509 (M), KY286933, KY286665, KY286843, KY286753, KY286587; Presliophytum sessiliflorum (Phil.) R.H.Acuña \& Weigend, Chile, Ehrhardt s.n. (M), KY286945, KY286676, KY286855, KY286765, KY286597; Scyphanthus elegans Sweet., Chile, Grau \& Ehrhardt 2-093 (M), KY286958, KY286689, KY286868, KY286778, KY286608; Scyphanthus stenocarpus (Poepp.) Urb. \& Gilg, Chile, Gardner \& Knees 8351 C (BSB), KY286992, KY286723, KY286902, KY286812, --; Xylopodia klaprothioides Weigend, Peru, Weigend \& al. 97/450 (M), KY286923, KY286655, KY286833, KY286743, --. 